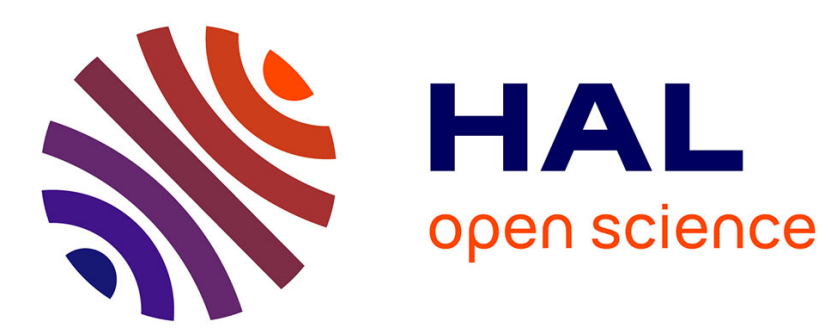

\title{
Corporate Profit, Entrepreneurship Theory and Business Ethics
}

Radu Vranceanu

\section{To cite this version:}

Radu Vranceanu. Corporate Profit, Entrepreneurship Theory and Business Ethics. 2013. hal00823521

\section{HAL Id: hal-00823521 \\ https://essec.hal.science/hal-00823521}

Preprint submitted on 17 May 2013

HAL is a multi-disciplinary open access archive for the deposit and dissemination of scientific research documents, whether they are published or not. The documents may come from teaching and research institutions in France or abroad, or from public or private research centers.
L'archive ouverte pluridisciplinaire HAL, est destinée au dépôt et à la diffusion de documents scientifiques de niveau recherche, publiés ou non, émanant des établissements d'enseignement et de recherche français ou étrangers, des laboratoires publics ou privés. 


\title{
Corporate Profft, Entrepreneurship Theory and Business Ethics
}

\author{
Research Center \\ ESSEC Working Paper 1308
}

2013

Radu Vranceanu 


\title{
Corporate Profit, Entrepreneurship Theory and Business Ethics
}

\author{
Radu VRANCEANU
}

ESSEC Business School

PB 50105, 95021 Cergy, France.

E-mail: vranceanu@essec.fr

$10 / 05 / 2013$

\begin{abstract}
Economic profit is produced by entrepreneurs, those special individuals able to detect and seize as yet unexploited market opportunities. In general capitalist firms manage to deliver positive profits even in the most competitive environments. They can do so thanks to internal entrepreneurs, a subset of their employees able to drive change and develop innovation in the workplace. This paper argues that the goal of profit maximization is fully consistent with the corporation doing good for society. However, there is little justification for corporations to transfer the whole economic profit to shareholders. Economic agents entitled to receive the economic profit are precisely those who create this profit, namely the internal entrepreneurs.
\end{abstract}

Keywords: Social role of business; Profit; Corporate goal; Internal entrepreneurs; Entrepreneurship Theory of the Firm; Virtue ethics.

(Forthcoming: Business Ethics: A European Journal. 2013, Wiley) 


\section{Introduction}

Despite the significant contribution of capitalist firms to the strong economic development of the world over more than three centuries, mistrust of their role in society remains in many countries, mainly in Europe. As noted by Primeaux and Stieber (1994: 287), "the business enterprise is besieged by popular misconceptions as well as by legal, religious and academic theorists anxious to prove that business seeks only self serving aggrandizement, i.e. to maximize its profits and to do so at any cost to the consumer, the community and the environment". The notion of profit is thus pivotal to any discussion of the role of business in society (Camenisch 1987).

The concept of profit, its origin and measure is extensively covered by the literature in economics. As proponents of economics as a positive science (Friedman 1966), the vast majority of economists have faith in the ability of the market economy to deliver the most efficient allocation of resources. They seldom explicitly address the question on whether the pursuit of profit by companies is ethical or not. ${ }^{1}$ On the other hand, the relationship between profit and the ethical conduct of business has been extensively studied by the business ethics literature. These studies differ in both their understanding of the economics of profit, and their ethical perspective. Most of them build their analyses on the neoclassical economics paradigm, and the assumption according to which the goal of a business is correctly approximated by the profit maximization objective; depending on their ethical stance, some researchers reach a relatively positive conclusion (Primeaux and Stiebert 1994); others are cautious (Hartman 2011), or critical. Other analyses rely on the ownership theory of the firm (Alchian and Demsetz 1972; Fama and Jensen 1983) and its assumption that shareholder-owned corporations should maximize shareholders' wealth. Most business ethics scholars are critical with respect to this claim; in general, they call for corporations to aim at serving all their stakeholders, or society at large (Schader 1987, Brown 1992, Blair 1995, Wagner-Tsukamoto 2007), although some endorse shareholder primacy on the grounds of an efficiency argument (Kierulff and Learned 2009, Gordley, 2002).

Through their production and innovation activities, firms make profits (and sometimes losses). "Pure economic profit" (Knight 1971) can be defined as the difference between a firm's income and all costs, explicit and implicit, incurred to deliver the goods or services sold. Thus, an accurate measure of economic profit should deduct, for all inputs, the "opportunity cost", that is, the value of the factor in its best alternative use. Unlike pure economic profit, "accounting profit" or "earnings" counts only the observed costs. If the firm's founder invests his own capital, the accounting profit will not capture the opportunity cost of using this resource for an alternative investment; in general, accounting profits exceed economic profits by far. Accounting profits and economic profits are certainly correlated, but the correlation is not perfect; information contained in the former is a biased measure of the latter, which is much more difficult to grasp. In this paper, the term "profits" refers to pure economic profits. ${ }^{2}$

While contemporary firms come in a variety of organization structures, this paper focuses on the large shareholder-owned corporation, which holds a pivotal role in the overall architecture of our economies but also attracts most of the criticism these days. Analysis is limited to firms abiding by the rule of law, which is considered as the most representative situation in developed economies. Situations where firms accumulate and abuse of market power, or undertake criminal activities, are

\footnotetext{
${ }^{1}$ This contrasts with the early years of economics, when pioneering writers were interested in both the operation of the economy and the ethical dimension of market relationships.

2 Accountants' attempts to capture economic profit led to the development of various metrics, such as Economic Value Added, introduced by Stern Stewart \& Co in the early nineties. In a nutshell, EVA is the profit earned by the firm less the cost of financing the firm's capital, including an estimate for the opportunity cost of equity. It is certain that all estimates of opportunity costs include a subjective element.
} 
not examined in this paper. Such illegal acts go against the interests of society and are unethical by any standard. This ethical inquiry into the economics of profits acknowledges the multiform nature of business, their multiple constraints, and the shifting expectations of society as regards the corporate role and responsibilities.

Our first research question is whether businesses making profits in a competitive environment is consistent with businesses doing good for society. The second important research question asks who are the legitimate claimants of the would-be positive profits.

Firms' goals and actions will be assessed mainly from a virtue ethics perspective (Anscombe 1958, MacIntyre 1981). This approach recognizes that outcomes and actions cannot be dissociated from the person herself. Following a line of argument that can be traced back to Aristotle's Nicomachean Ethics, virtuous people can take only good action, so ethics is primarily about defining virtues, that trait of character which allows the person to provide the appropriate response in a given context. This perspective is found a few centuries later in St. Thomas Aquinas Summa Theologica (St. Thomas Aquinas 1485). ${ }^{3}$ Several scholars argued that virtue ethics might provide the most suitable channel for analyzing ethical issues pertaining to business situations, since this approach is able to strike a subtle balance between determinism (i.e. the external constraints on the individual's behavior) and human character (see, inter alia, Koehn 1995, Murphy 1999, Solomon 1992, 2003, Vranceanu 2005, 2007, Moore 2008, Audi 2012). Profits have been analyzed in a virtue ethics perspective by Gordley (2002) and Hartman (2011). In general, virtue ethics tends to consider that Man is intrinsically good, or at least is aiming for good; this stance has the potential to upset some critics of the business world who picture competition as ruthless and brutish.

The origin of (economic) profits in a competitive environment has exercised many generations of economists. ${ }^{4}$ Economics is dominated today by the neoclassical approach, whose origin can be traced back to the writings of XIXth and XXth Century authors such as Stanley Jevons, Francis Edgeworth, Alfred Marshal, Vilfredo Pareto and Leon Walras. This paradigm imposed the concept of perfect competition, an ideal system where information is perfect, transactions are frictionless, firms and consumers are small enough to have no impact on prices, branding and all other forms of product differentiation cannot be applied, and firms can enter and exit without cost. Furthermore, firms are assumed to maximize profits, and consumers are assumed to maximize utility from consumption. Within this set of hypotheses, it has been shown by Kenneth Arrow and Gerard Débreu in the 1950s that there is one vector of prices that clears all markets simultaneously. The neoclassical world of perfect competition is still: in equilibrium, every market participant does the same thing as everyone else, and since inputs are rewarded at their marginal contribution to output, firms make zero economic profits. If a shock throws the system out of this "general equilibrium", market forces are expected to bring it back smoothly to its original state where (all) markets clear. The Ownership Theory of the Firm extended these principles to the modern shareholder corporation, with some qualifications. In particular, the goal of the corporation was reinterpreted as maximizing shareholder value. As will be shown later on, the consequences of this seemingly innocent change are far from innocuous.

A different perspective on capitalist firms and competition was developed by the Austrian school of economics, to mention here only the contributions of Joseph Schumpeter, Friedrich Hayek, Ludvig von Mises and Israel Kirnzer. These scholars observed real world competition and noticed that firms continuously fight to outdistance their rivals by bringing into being new ideas, different products and better practices. In this context, prices move continuously in order to signal changes, and the rebalancing dynamic of markets never ceases. Participants in a market cannot "plan" in the engineering sense - they cannot solve an optimization problem as such, since the constraints of the

\footnotetext{
${ }^{3}$ In the early years of successful capitalism, Adam Smith (1759) recommended prudence, i.e. "wise and judicious conduct", as the "most ennobling of virtues" (Smith 1759: 253).

${ }^{4}$ See Knight (1971) for a survey of the main evolutions of economic thought in this area.
} 
program are not established before the action of the agent is implemented. In this moving economy, prices help reveal change, and profit stimulates entrepreneurs' awareness of untapped opportunities. In a nutshell, Austrian economics sees competition as a process, while neoclassical economics describes it as the state of the economy as it results from this process.

In order to perform our ethical analysis of profit, this paper develops an Entrepreneurship Theory, extending the Austrian economic theory of the firm to the shareholder-owned corporation. The key concept is that of the entrepreneur, a special individual able to observe and remove existing inefficiencies in the economic system. An established strand of research in management research studies "modern" organization forms that sustain entrepreneurship within the firm, referred to as internal or corporate entrepreneurship (inter alia., Peterson and Berger 1971, Burgelman 1983a, 1983b, Jones and Butler 1992, Pinchot and Pinchot 1993, Moore 2008; see Zahra (1999) for a survey). Years ago Schumpeter (1911) underlined that employees in large firms can be at the origin of "new combinations" that create value for the firm. Jones and Butler (1992: 735) define company entrepreneurship as "the process by which firms notice opportunities and act to creatively organize transactions between factors of production so as to create surplus value". In line with Kirzner's (1989) finder-keeper principle, we argue that these internal entrepreneurs deserve any positive economic profits. This argument calls into question the relevance of the corporate goal of maximizing shareholder value, as advocated by proponents of the ownership theory of the firm.

The rest of the paper is organized as follows. The next section defines the capitalist firm and presents its social role. Section 3 discusses the standard neoclassical perspective on the economy, and investigates the ethics of profits in that context. Section 4 presents the Austrian perspective on the competitive economy, defines profits in this dynamic approach, and analyses its ethical content. In section 5, the ethic of profit analysis is extended to the modern shareholder-owned corporation; a brief comment on the social responsibility of firms is also introduced. The last section presents the conclusion.

\section{Contemporary firms: social role, forms of organization and ownership structure}

In modern societies, human beings satisfy their basic material needs by buying goods and services on markets where firms supply those goods and services. Firms must also anticipate future needs and create as yet non-existent goods that people will want to buy. The direct social role of business is thus twofold: production (of goods and services) and innovation. Indirectly, firms also provide individuals with jobs and opportunities to invest their savings, thus guaranteeing the flow of income needed to acquire the demanded goods and services. Furthermore, by continuously incorporating technical progress, they allow wages to increase steadily, in line with productivity gains.

The size of the contemporary capitalist firm varies, from the self-employed individual to the huge multinational employing thousands of workers throughout the world. Why do people group together in order to produce goods for the market, rather than making them by themselves in autonomous production? Many years ago Adam Smith provided an illuminating explanation: when each individual specializes in a particular task, the productivity of the group turns out to be larger than the sum of individual productivities. By allowing the highest degree of individual specialization while managing the resulting complexity, firms are extremely efficient systems of producing goods (Dobb, 1929).

Yet, as noted by Coase (1937), this reason alone does not explain why, once in a firm, individuals give up coordination through prices, and agree to obey a hierarchy that allocates resources by a centralized decision process. Coase's transaction cost theory provides an interesting answer, by bringing into the picture all the costs of resorting to the market, and comparing them with the cost of organizing production within a firm. The hierarchical firm will internalize upstream levels of production when organization costs are lower than the "transaction costs" connected to uncertainty about future outcomes, bounded rationality or imperfect information (Coase 1937, Williamson 
1985). Coase defines the firm as "the system of relationships which comes into existence when the direction of resources is dependent on an entrepreneur" (Coase 1937: 393). This perspective is close to the neoclassical perspective of the economy; the "entrepreneur" is represented as an organizer, able to weigh up the multiple costs and benefits of each organizational form, and choose the most efficient one. ${ }^{5}$ Then, as Fama and Jensen (1983: 301) argue, "the form of organization that survives in an activity is the one that delivers the product demanded by customers at the lowest price while covering costs".

Williamson (1983) pointed out that in the early part of the $20^{\text {th }}$ century, the hierarchical, highly centralized organization form with departments specialized by functions (U-form) was replaced by the multidimensional form (M-form), "in which semiautonomous operating divisions (mainly profit centers organized along product, brand or geographic lines) were created and strategic decisions were sharply distinguished". ${ }^{6}$ The success of the M-form was considered to stem from its ability to free the top management from short-run operational work, and allow them to focus on long-term, strategic decisions.

Today most innovative firms rely on hybrid organization structures, with a high degree of disaggregation, where many activities are housed in sub-units that are managed in much the same way as external subcontractors (Zenger and Hesterly 1997). Modern firm theories sometimes describe them as "intelligent organizations" aiming to unleash employees' creativity and "intrapreneurial" initiative, as opposed to bureaucratic organizations based on hierarchical structures of command and communication (Pinchot and Pinchot 1993). Actually, these forms of organization bring prices and market-based incentives back into the firm.

Firms also differ in their ownership and control structures, from the self-employed self-managed firm to the large firm run by a professional manager, often incorporated as a public corporation with financial resources provided by a myriad of shareholders on a limited liability basis. Focusing on this dimension, the classic legal definition of the firm (and in fact of any organization) was provided by Fama and Jensen (1983: 302):

\section{"An organization is the nexus of contracts, written and unwritten, among owners of factors of production and customers. These contracts or internal "rules of the game" specify the rights of each agent in the organization, performance criteria on which agents are evaluated, and the payoff functions they face."}

In this "ownership theory of the firm", the emphasis is on the contracts between the various stakeholders that define the rights and duties of each person who interacts with the company. The legal approach has substantially clarified understanding of the operations of large, listed corporations, but may also have played down the role of internal entrepreneurs.

As in any legal theory, each contracting party is assigned a role ex-ante, before entering into the exchange. For instance, employees agree to provide labor services at a predetermined wage, customers agree to pay the price to have the goods, the manager agrees to run the company, and each party knows what role he will play from the outset. But in the real world, the entrepreneur does not necessarily know he is an entrepreneur before he becomes one. And he can only become one through practice, as a participant in the production and innovation process. It is much more difficult to write a contract that recognizes such a contribution ex-post. As we show later on, modern firms do so, but this way of doing business does not fit well into the ownership theory of the firm.

\footnotetext{
${ }^{5}$ As shown later, this view is challenged by the Austrian economics school of thought.

${ }^{6}$ Williamson (1983) notes that most large corporations in 1932 were of the U-form; they adopted the M-form in 1945-1960. This transition process was first documented by Alfred D. Chandler in his Strategy and Structure (Chandler 1966).
} 


\section{Firms and profit in the neoclassical view}

\subsection{The origin of profits}

At its origin, the main goal of the neoclassical research programme was to produce a theory of prices, more precisely to explain how prices are determined in a competitive economy. ${ }^{7}$ In the pursuit of this ambitious goal, neoclassical economics introduced many simplifications of reality, including a stylized but realistic representation of a producer's objective.

In the standard approach, the firm is represented by a "production function" i.e., a formula that shows how inputs are combined in order to get the final product. Most neoclassical analyses of the firm do not go into organization details; the firm is represented as a "black box", and all technological and economic issues collapse into the cost function that relates the cost of producing the output to its volume. This approach implicitly assumes that firms are hierarchical organizations; within the firm, resources are combined to arrive at the final product through a production plan that monitors quantity flows; all functional activities, including top management, are subordinated to the goal of efficient production. ${ }^{8}$

When the firm is managed by an entrepreneur who gathers together the resources needed to produce a given output, it is realistic to believe that his aim is to maximize the net expected return from his activity over a long run period. Why the expected return, not the certain return? Because nobody can predict the exact state of nature at a later time; at best, individuals can assign probabilities to all possible states of nature (and the related return), and thus determine the expected return as a probability-weighted average of all possible returns.

Maximizing expected returns means that, given the available technology and input prices, the ownermanager should first choose the least expensive combination of factors for every production level. Then, the manager should plan for the highest expected income. To do so, he will make his best guess of how demand will respond to changes in prices, and use his knowledge of the cost function to decide on the optimal price-output combination. For complex activities the manager may be unable to solve the optimization problem analytically, and will find his way toward the most efficient combination through a trial-and-error learning process. A theory built on the optimization principle can thus be seen as a workable approximation of a much more complex decision-making process of the kind observed in the real world.

In the theoretical perspective of pure competition, the firm has little impact on the market price of the goods it supplies to the market and on its input prices. Whenever firms make positive profits, new firms enter this market, the supply increases and the price falls, which drives (economic) profits down to zero. Firms maximize profits, but this maximum profit is zero.

Pushing on with the neoclassical reasoning, if a firm makes positive (economic) profits in the long run, this is representative of some form of market power, i.e. a deviation from pure competition that allows it to set prices above the marginal cost. If the theorist cannot see why this is the case, he would guess that something is preventing new firms from entering the market. Competition policy and law in Western economies is very sensitive to this argument; abuses of market power are considered as major fraud, and (when proved) attract sanctions similar to those for violent crime. There is one major exception to this principle: in order to stimulate companies to engage in risky R\&D activities, all Western countries have adopted the patent system, which legally entitles a

\footnotetext{
7 This claim should not be understood as an attempt to underestimate the substantial contribution of neoclassical economics in understanding other dimensions of economic life. However, if something goes wrong somewhere, the first reaction of the neoclassical economist will be to search what brought about a deviation from the ideal competitive equilibrium (transaction costs, asymmetric information, convexities in the production function, etc).

${ }^{8}$ of course, many modern studies in industrial organization, personnel economics and economic organization go beyond this parsimonious summary of the neoclassical project.
} 
company that innovates to exclude others from replicating its new product or technological process for twenty years. Experts continue to debate whether such "legal" abuses of market power, which are detrimental to short-term efficiency, are worth tolerating for the sake of dynamic efficiency.

\subsection{The ethics of profits}

Because firms are now a ubiquitous presence in our lives, we sometimes fail to realize the importance of their function of providing us with goods and services that make our lives easier, not to say better. To take only one example, the generation born in the 1960s has grown up with the epic rise of computing, driven by firms such as IBM, Intel, Microsoft, Apple, Oracle, Sun, Cysco, and many others. Thanks to computers' power and speed in processing information, huge progress has been achieved in almost all domains of human activity, from education and medicine to manufacturing, transportation, space technology and biotechnology. The advent of computers fuelled an information revolution with a comparable social impact to the Gutenberg printing press in the $15^{\text {th }}$ century. Who could now imagine a world without Internet and the companies such as Google, Facebook or Twitter that have made it such a success story? Their contribution to society goes far beyond fulfilling basic human needs, extending to granting free access to information in remote areas or countries where human rights are still under threat. So in free market economies, firms perform their social role when they produce goods and services that people demand, or may demand in the future. ${ }^{9}$

Thus in competitive markets, profit maximization creates jobs in the production process and brings to the market the goods wanted by consumers at the smallest possible cost given the technological constraints. This generates the largest consumer surplus, defined as the difference between what consumers would be willing to pay and what consumers must pay to get the goods. In this context, the "good" of the company is also "good" for everyone else.

This is the argument emphasized by Primeaux and Stieber (1994: 289). They claim:

"When business men and women profit maximize, i.e. allocate resources efficiently, people have more of the things they want, and that is good. When they do not profit maximize, i.e. allocate scarce resources inefficiently, people have less of the things they want, and that is bad".

This good ethical outcome, outlined many years ago by Adam Smith, the father of modern economics through the "invisible hand" metaphor, is obtained passively, in an unintended manner, by firms driven by self-interest only, what Wagner-Tsukamoto (2007) defined as the "level one" of the moral agency of the firm. Goodpaster and Mathews (1982) referred to this ability of market competition to deliver an ethical quality independent any moral projections of the managers as the systemic morality of the market economy.

Yet, in a virtue ethics perspective, the manager of a hypothetical neoclassical firm might well go beyond this amoral decision making. According to Athannassoulis (2004), Aristotle observed that where something has a function, the good of the thing is when it performs its function well. For example, the knife has a function, to cut, and it performs its function well when it cuts well. Since the manager of a company who seeks to maximize profits must firstly minimize costs, the goal of good use of scarce resources is high on the agenda of the neoclassical firm. But waste-avoidance through good judgment is a virtue and must be recognized as such.

Real world differs from the neoclassical model of perfect competition in many respects. Many neoclassical economists agree that the state should step in and correct market failures or unacceptable wealth inequality (Bénabou and Tirole 2010). Such coordination failures could occur for

\footnotetext{
${ }^{9}$ By contrast, in the now almost defunct socialist economic system, firm production was controlled through a bureaucratically designed central plan; many goods and infrastructures were produced with no other purpose than to fulfil some political leader's absurd self-aggrandisement goal, while ordinary people would spend hours waiting in line to get basic goods such as milk or sugar.
} 
instance when satisfactory contracting solutions require excessive transaction costs or when contracting parties hold asymmetric information.

In particular the society (parliament/government) has the ability to redress the balance through business laws, which can be interpreted as codified ethics. Typical situations involve environmental taxation, prudential regulation, and regulation of network industries. Another departure from the theoretical model of perfect competition is market power. Systematic positive profits would in fact indicate an abuse of market power, and this abuse is banned by competition laws throughout the world.

As Wagner-Tsukamoto $(2005 ; 2007)$ points out, that form of morality codified in laws that constraints the profit maximizing behavior of firms makes up for the "level two" of business ethics; he also notes that economists who were strong proponents of the free-market economy, such as Milton Friedman or James Buchanan, were fully aware of the necessity of a strong legal framework for businesses.

As already mentioned, the main achievement of neoclassical economics was to provide an elegant and so far unchallenged explanation of price formation in a decentralized economy; however, in order to overcome the difficulty of the problem, general equilibrium economists used an extremely simplified description of the economy. In particular, in the competitive equilibrium, all firms copy each other, adopt the same technological and production choices; they end up producing the same amount at the lowest average cost and make zero economic profits. While there is no doubt that in this virtual world consumers would be satisfied with getting the goods at the lowest possible price, this does not teach us much about the hopes and motivations of the people who create firms, come up with new ideas, innovate, strive to do better than the rest. In other words, the neoclassical theory does not have much to say about human values, other than the (admittedly important) satisfaction of having things done in a very efficient way.

\section{Firms and profit in the Austrian perspective}

\subsection{The origin of profits and the entrepreneur}

A different approach to competition, defined as a process rather than the state that results from the process, has been advocated by the Austrian School of Economics. Its scholars emphasize the differences between the real world - living, thus changing - and the abstract microeconomic model developed by their neoclassical fellows.

Austrian economists do not seek to explain how prices are determined, but study instead the role of prices in the market economy. In his masterpiece, The Role of Knowledge in Society, Friedrich Hayek (1945) argued quite convincingly that (1) in the decentralized economy the system of prices conveys to economic agents all information they need in order to implement their economic choices (2) and that there is no alternative to this coordination mechanism. He states:

"It is more than a metaphor to describe the price system as a kind of machinery for registering change, or a system of telecommunications which enables individual producers to watch merely the movement of a few pointers, as an engineer might watch the hands of a few dials, in order to adjust their activities to changes of which they may never know more than is reflected in the price movement." Hayek (1945: 527)

Contrary to neoclassical economics, where agents rely on observed prices to work out optimal production or consumption plans, in the Hayekian approach, prices signal change, and this change is by definition a continuing process. The coordinating role of prices is achieved through ongoing movement that triggers quantity adjustments. As Hayek (1945) wrote:

"The marvel is that in a case like that of a scarcity of one raw material, without an order being issued, without more than perhaps a handful of people knowing the cause, tens of thousands of people whose identity could not be ascertained by months of investigation, are 
made to use the material or its products more sparingly; i.e., they move in the right direction." Hayek (1945: 527)

In a line of reasoning that can be traced back to the early writings by Joseph Schumpeter (1911), economic profits can appear in such a dynamic and lively competitive environment, as opposed to the neoclassical "steady" competition, because some people - the entrepreneurs - have the ability to spot small imperfections in the way these markets function, and to be the first to take advantage of those inefficiencies. Hence the concepts of "economic profit" and "entrepreneur" are deeply interconnected. ${ }^{10}$

In this perspective on competition, the entrepreneur is a person able to seize opportunities to produce better than others; he can test new products, new production techniques, new organization forms. This requires special skills such as heightened awareness, but also specific traits of character, such as perseverance, high-mindedness and courage.

A clear account of the social role of entrepreneurs is provided by Ludvig von Mises in his masterpiece, Human Action:

"Like every acting man, the entrepreneur is always a speculator. He deals with the uncertain conditions of the future. His success or failure depends on the correctness of his anticipation of uncertain events. If he fails in his understanding of things to come, he is doomed. The only source from which an entrepreneur's profits stem is his ability to anticipate better than other people the future demand of the consumers. If everybody is correct in anticipating the future state of the market of a certain commodity its price and the prices of the complementary factors of production concerned would already today be adjusted to this future state. Neither profit nor loss can emerge for those embarking upon this line of business. (Von Mises 1949: 290)."

Knight (1973) made a substantive contribution to this analysis by pointing out that risk - a situation where the individual can assign probabilities to the various states of nature that will determine the future outcome of any project - cannot justify economic profit; there should be a price for such risk, and this price is charged by those who bring capital to the firm. Only pure uncertainty specific to situations where "we don't know that we don't know" can justify economic profits. ${ }^{11}$.

The logical link between prices as signals of change triggering appropriate action of market agents in Hayek's writings, and profit as an incentive for entrepreneurs to remove inefficiencies prevailing in a competitive environment, was further developed by Israel Kirzner, according to whom:

"Profits are to be found where available bits of information have not yet been coordinated. The exploitation of profit opportunities consists in identifying and correcting uncoordinated groups of plans". (Kirzner 1973: 222)

..

"The essence of the "profit incentive" (and in particular its significance for normative economics) is thus not to be seen as motivation to work harder or to allocate resources more efficiently. The profit incentive (including, of course, the disincentive of loss) operates most significantly by sparking the alertness of entrepreneurs - by encouraging them to keep their eyes open for new information that will lead to new plans". (Kirzner 1973: 223)

In a later book, Kirzner (1989) points out that entrepreneurship is driven by the "discovery principle": some individuals, motivated by positive gain, are striving to anticipate future needs, identify better

\footnotetext{
${ }^{10} \mathrm{~A}$ first clear account of the relationship between profit and entrepreneurship can be found in the writings of John Bates Clark (see Clark 1914).

${ }^{11}$ The distinction drawn by Knight between risk and uncertainty can be found in a recent field of research in decision theory dedicated to ambiguity. Ambiguity arises when individuals cannot attribute even subjective probabilities to future events.
} 
techniques, take risks and innovate. This psychological attitude guides everyone in day-to-day decision-making, but only some gifted individuals, the entrepreneurs, can transpose it to the business universe where goods and services are created. It should be noted that by pursuing their self-interested goal - to capture an ephemeral profit - entrepreneurs make everybody better off in the future, since future transactions will take place at undistorted prices. If their idea is successful, everyone else will benefit from it in the future: both consumers and copycat rival producers.

While Austrian economists believe that the profit motive is the main driver of entrepreneurship, the goal of the entrepreneur is arguably not accurately described by the concept of profit maximization, since the entrepreneur cannot "plan" in the engineering sense so dear to neoclassical economics: the set of constraints is unclear, some of them are actually unknown at the time the decision is taken, prices will move in response to the entrepreneur's action, competitors will react, and all this happens in a chain of events that cannot be fully foreseen. In fact, until such an entrepreneur comes up with an idea, the (neoclassical) production process does not exist (Kirzner 1989). This brings us back to Friedman's (1966) remark - the entrepreneur can maximize the expected return (which takes into account probabilistic risk), but any positive economic profit achieved is purely the outcome of his entrepreneurial behavior and of the Knightian uncertainty around decisions. The goal of the entrepreneur is thus to make a positive economic profit, and increase it as much as possible over time. His aim is a kind of "profit maximization", but the underlying process differs between the Austrian approach and the neoclassical approach.

\subsection{From external to internal entrepreneurship}

Following the major change from the U-form to the $\mathrm{M}$-form in the $20^{\text {th }}$ Century, contemporary firms have adapted their organization to cope with the challenge of breeding entrepreneurial behavior within the firm. Zenger and Hesterly (1997) observed a tremendous organizational shift in large US firms toward what they call "hybrid organizations" with blurred firm-market frontiers. In their view, modern business systems are made up of a network of small exchanging teams, factories, divisions, subunits, and firms that govern design, production, marketing, and delivery, and the question of whether the boundaries between those entities are internal or external is increasingly irrelevant.

Many contemporary firms with tens, hundreds or sometimes thousands of employees, have managed to bring entrepreneurship inside the boundaries of the organization. ${ }^{12}$ This has enabled them to stay at the top for many years, despite a highly competitive environment and many technological changes. As noted by Pinchot and Pinchot (1993):

\section{"Many of the virtues of the free market can be brought inside the corporation. When intrapreneurs have more of the rights, responsibilities, and challenges of entrepreneurs, the system acquires the permanent speed and adaptability of a network of entrepreneurial firms (p. 17 intro)".}

Intelligent organizations can indeed create an environment where entrepreneurs can express their talent within the company. Providing entrepreneurs at all levels with the right incentives and room for action is itself an entrepreneurial action for the top management. Many companies have implemented sophisticated performance-related pay systems with the aim of reinforcing behavior that best serves the corporate business strategy (Lawler 1990). Some types of performance-related pay can be seen as systems for transferring economic profits to the people who generated them.

Stock option plans, widely used in the IT sector to reward bright researchers who join a start-up company, provide a typical example of how profits go to the people who contribute most to the project's success through their ideas and creativity. Indeed, when such an "entrepreneur" exercises

\footnotetext{
12 Burgelman (1983a, 1983b) was among the first to call for the development of "internal corporate venturing" leading to corporate entrepreneurship. See Zahra et al. (1999) for a survey on the corporate entrepreneurship literature.
} 
his option (i.e. buys a share at a pre-committed, below-market price), this operation will transfer some profit from regular shareholders to him.

That companies should be as innovative as possible is an internal requirement of any competitive environment, where weak firms (read: firms that make losses) are gradually pulled out of the market. While "survival of the fittest" explains why companies adapt their organization form in order to improve performance, it is not obvious who the driving agent is. One thing is certain: top management should be in charge of implementation of the process; whether they do it for their own sake, as the main beneficiary of the change, or on behalf of shareholders remains an open question.

\subsection{The ethics of profits in the Austrian perspective}

Like the neoclassical economists, Austrian economists generally acknowledge that in a market economy the pursuit of self-interest by the entrepreneur is aligned with the good of everyone else, and his interested objectives are unattainable if he does not care about others:

"[The entrepreneur] is driven solely by the selfish interest in making profits and in acquiring wealth. But he cannot evade the law of the market. He can succeed only by best serving the consumers. His profit depends on the approval of this conduct by the consumers." (Von Mises 1949: 290)"

In the Austrian economics paradigm, positive profits can be obtained in the most competitive markets simply because markets are systematically in disequilibrium, and entrepreneurs, through their action, help remove these inefficiencies by means of a solution, an idea, or an appropriate price. The continuous race to detect inefficiencies provides entrepreneurs with what neoclassical economists would consider as a form of temporary market power, but it is by no means harmful, quite the contrary: once the inefficiency is removed, consumers will benefit from the better resource allocation forever.

Kirzner (1989) argued that entrepreneurs should be the legitimate claimants of these profits. Just as the archeologist has the right to keep the hidden treasure he risked his life to find, the entrepreneur has the moral right to keep the profit he has created, on the same finder-keeper principle. Arnold (1987) carries this argument over to the business ethics literature, and emphasizes that Kirzner's analysis explains why entrepreneurs deserve the profits they bring into existence. He then argues that the social rule that allows entrepreneurs to keep the profit is better than any alternative since it promotes the essential goal of the market, i.e. to allocate resources in the most efficient way over the long run. He states three reasons for this claimed superior performance: (1) without the profit lure, no one would spend any time or effort on correcting resource misallocation (and this would harm society as a whole), (2) since most entrepreneurs would reinvest their profits, it is optimal to provide resources to those who have already proved that they can use them well, and (3), high profits would show competitors the path to follow.

In the virtue ethics approach, Goldreyer (2002) observes that in the writings of both Aristotle and St. Thomas Aquinas, making profit is good insofar as the person must exercise good judgment to achieve it. When entrepreneurs apply good judgment to the issue of how to avoid waste in production, how to produce a better product or how to create a new product or production process, the quest for profit is consistent with the quest for excellence. Good judgment is necessary but not in itself sufficient for good behavior. If the entrepreneur seeks the profit to satisfy his own purposes, those purposes themselves must be good, otherwise good judgment is vain. As St. Thomas Aquinas emphasized, such good purposes may be to have a fulfilling life, to help the poor, or to help the country. If entrepreneurs are good people, then not only do they deserve the profits, but we can also trust them to use them wisely.

The motivation driving entrepreneurs may encompass more than narrow economic goals. In a virtue ethics perspective, Cornwall and Naughton (2003) refer back to Maclntyre's (1984) analysis of craftsmanship to emphasize that the quest for excellence - to do the job well - is part of the 
entrepreneur's motivation, and reinforces the traits that make him a good person. Non-profit goals are hard (but not impossible) to integrate into the neoclassical analysis, but not in the Austrian economics approach, quite simply because it emphasizes decisions by "real people" rather than abstract "representative agents".

\section{Profits and the modern corporation}

\subsection{The ownership theory of the firm - the shareholder King}

These days, a substantial share of output in both developed and emerging economies is delivered by large firms, most of them incorporated under a limited liability status. Many of them are publicly listed, with capital owned by a large number of shareholders.

When it comes to analyzing the scope, organization and operation of these firms, the legal approach presenting the firm as a nexus of contracts (Fama and Jensen 1983) has reached a substantial academic success. Shareholders hold a special place in this paradigm since they agree to bear the first losses if "bad luck" (read: bad decision-making or a deteriorating environment) strikes. ${ }^{13}$ According to Fama and Jensen (1983: 309):

"The contract structures of most organizational forms limit the risks undertaken by most agents by specifying either fixed promised payoffs or incentive payoffs tied to specific measures of performance. The residual risk-the risk of the difference between stochastic inflows of resources and promised payments to agents - is borne by those who contract for the rights to net cash flows. We call these agents the residual claimants or residual risk bearers".

With shares providing ownership rights to the future net cash flow, the market value of a company is given by the discounted expected returns. As a natural corollary, the profit maximization goal as expressed by the neoclassical economists has been equated by proponents of the ownership theory of the firm with maximization of shareholder value. A fully-fledged theory of corporate finance has been built on this assumption. ${ }^{14}$

The idea that the manager should run the firm solely in the interest of shareholders dominated the US legal approach to the corporation in the $19^{\text {th }}$ and early $20^{\text {th }}$ century (Blair 1995). In a widely-cited example, in 1919, when the Dodge brothers, who were shareholders of the Ford Corporation, sued Ford for investing 58 million dollars in business expansion and price reductions, the judge took their side:

"A business corporation is organized and carried on primarily for the profit of the
stockholders. The powers of the directors are to be employed for that end. The discretion of
the directors is to be exercised in the choice of means to attain that end, and does not
extend to a change in the end itself, to the reduction of profits, or to the non distribution of
profits among stockholders in order to devote them to other purposes. (204 Mich. 459,170
N.W. 668.)"

However, this view was later challenged because shareholders do not exert ownership rights in the same way as a sole owner of his enterprise (Brown 1992). The basic argument was stated long ago by Bearle and Means (1932), who argued that shareholders were passive owners at best; they

\footnotetext{
${ }^{13}$ Alchian and Demsetz (1972: 791) argued that "residual claimants - owners of the firm - will be investors of resalable capital equipment in the firm".

${ }^{14}$ Economists have observed that there can be conflicts of interest between the manager hired to run the company and shareholders (Jensen and Meckling 1976), and shown how to write incentive-based contracts in order to align the CEO's goals with that of the shareholders. Assuming that managers are more risk-averse than shareholders with a diversified portfolio, these studies argued that a variable portion of the CEO's compensation should be connected to the market value of the company.
} 
effectively only exercised the power to sell their shares if dissatisfied with corporate policies or performance. "By surrendering control and responsibility over the active property, [shareholders] have surrendered the right that the corporation should be operated in their sole interest..." (Bearle and Means 1932: 355). These two authors commented that this does not mean the company should be run for the benefit of the management ("controlling groups"); on the contrary, it should be open to a broader range of constituencies.

The law of New Jersey - where most US firms are incorporated - was amended in the 1930s to allow corporations to make charitable contributions to the community. ${ }^{15}$ The case that helped redefine the purpose of corporations was the famous A.P. Smith Manufacturing Co. vs. Barlow, New Jersey Supreme Court, 1953 (Hood, 1998). In 1951, the board of directors of A.P. Smith, a manufacturer of valves and fire hydrants, adopted a resolution to donate $\$ 1,500$ to Princeton University. Corporate shareholders challenged the donation as being outside the proper scope of corporate expenditure as defined by the 1930 law. The court disagreed:

\section{"[Shareholders], whose private interests rest entirely upon the well-being of the corporation, ought not to be permitted to close their eyes to present-day realities and thwart the long-visioned corporate action in recognizing and voluntarily discharging its high obligations as a constituent of our modern social structure."}

Such legal practice and open criticism cleared the way for an alternative theory of the firm. After the influential work of Freeman (1984), social scientists acquired the habit of referring to the distinct groups of people affected by the corporation in the pursuit of its activity as stakeholders. In general, the literature designates employees, customers, government and the community as the main stakeholders; some researchers include shareholders as well. Many scholars have argued that a firm's goal should not be profit maximization, but a much wider objective such as to create "value for society". Blair (1995), for instance, argues that managers of the corporation should maximize the "total wealth creating potential", which includes the interests of all actors who place themselves at risk by dealing with the firm. Unfortunately, while such goals are appealing, they lack theoretical foundations and are too vague; furthermore, different stakeholders may have conflicting goals (Vranceanu, 2005).

\subsection{An "entrepreneurship theory of the firm"}

A new perspective on corporate goals and action would build on an entrepreneurship theory of the firm, inspired by the Austrian economics approach in which the key requirement for the long-run success of the firm is its internal entrepreneurs. Jones and Butler (1992: 735) define internal entrepreneurship as "the process by which firms notice opportunities and act to creatively organize transactions between factors of production so as to create surplus value". Companies able to continuously reinvent and generate a steady flow of ideas and innovations abound, to cite here only the example of IBM, which has managed to stay at the top for more than a hundred years despite three major technological changes (The Economist, 2011).

In the standard example, the large corporation started out as a relatively small firm created by an entrepreneur. The world's biggest conglomerate today, for instance, General Electric with its turnover of $\$ 150$ bn in 2010, has grown up from Thomas Edison's original 1890 company. As the scale of business expands, the entrepreneur needs to raise additional capital resources, and he may have new projects to implement. He will therefore raise funds on the external capital market by issuing debt and shares, each instrument having its own specific risk and cost. At some point in time, the initial entrepreneur may have to exit the organization, and a professional manager may take over, but the company can still produce a steady flow of innovation.

\footnotetext{
${ }^{15}$ As long as a donation did not exceed one percent of the company's capital stock, the board was not required to notify the shareholders.
} 
A recent structural change in the way firms are created started in the USA in the early 1970s with the development of venture capital, i.e. investment societies specialized in high risk-high and high potential companies. Many "new economy" firms such as Apple, Genentech, Intel, Lotus and Microsoft have been backed by venture capital (Gompers and Learner 2004). An entrepreneur will thus be able to finance his idea if he convinces a venture capitalist to share the risk of the project.

Alternatively, "entrepreneurial genes" may have been lacking in a company's beginnings, but successive waves of transformation, technological change and strong leadership subsequently created an internal environment favorable to idea generation and innovation. A company with entrepreneurial genes has an organizational form that can generate new ideas better than others; it can stay at the top even when the environment is extremely competitive.

If we take this entrepreneurship perspective, the company can still be depicted as a nexus of contracts, but shareholders are no longer the legitimate claimants to economic profit. In a competitive environment, the legitimate claimants to economic profits are the economic agents who internally perpetuate the entrepreneurial spirit and actually create these profits, i.e. the internal entrepreneurs. They may be employees, middle managers, managers of business units or the CEO. Sometimes shareholders are involved in entrepreneurial action, since they can influence strategic choices, force through innovative re-organization, etc. In such cases, they too may be entitled to a share of economic profits.

This idea was clearly stated by Kirzner (1973), but he considered that a professional manager is the key perpetrator of entrepreneurship in the corporation. Blair $(1995$, p.234) broadened the perspective by observing that, "much of the wealth-generating capacity of most modern firms is based on the skills and knowledge of the employees and the ability of the organization as a whole to put those skills to work for customers and clients." On similar lines, Jones and Butler (1992) argued that entrepreneurship can be generated at various decision levels; top management may or may not be entrepreneurial.

But do corporations distribute economic profit to shareholders? Or this is no more than a modern myth? According to standard accounting principles, firms transfer the after-tax earnings (accounting profit) to shareholders through dividends or new investments in the firm (that raise the share value). But many variable wage components are actually transfers of economic profit to internal entrepreneurs. Although shareholders seem to be paid last, this is only an illusion. In fact, a large proportion of net returns will be redistributed to the staff and CEO according to a system of precommitted variable claims. ${ }^{16}$ In modern corporations, many resources, bonuses and incentives are contingent upon performance (Lawler 1990). Pay in the form of stocks and stock options for CEOs and top executives is almost standard in today's corporate world. Start-ups in high-tech industries also use stock options to compensate their most dynamic staff. After the Great Recession the quest for higher competitiveness become a main concern for many CEOs and bonuses for "exceptional performance" tend to be generalized in many organizations. All these compensation instruments transfer actual and future economic profits to internal entrepreneurs, a subset of the company staff. $^{17}$

This brings us back to the question of the corporate goal. Shareholder-owned corporations, like other business organizations, fulfill their social role when they produce goods and services in the most efficient way. They should strive to innovate, to bring new ideas into being, to produce goods in

\footnotetext{
${ }^{16}$ In general, the ownership theory of the firm assumes that most of these claims are fixed.

${ }^{17}$ It should be noted that a staff member's entrepreneurial contribution can be assessed only ex-post, once the product or process has been launched. Furthermore, the set of entrepreneurs varies from one period to another.
} 
better ways or to produce new goods. This means that such corporations should make positive economic profits and seek to increase them over time, as Milton Friedman stated long ago: ${ }^{18}$

"...there is one and only one social responsibility of business - to use its resources and engage in activities designed to increase its profits so long as it stays within the rule of the game, which is to say, engages in open and free competition, without deception or fraud" (Friedman 1962: 133).

Since the economic profits of the entrepreneurial corporation need not be transferred to shareholders according to a rigid sharing rule, the company that maximizes value (or future profits) does not need to maximize "shareholder value". In an extreme case, the corporation will provide shareholders with a relatively stable income equal to the opportunity cost of capital ${ }^{19}$, and transfer all economic profits to internal entrepreneurs. Thus maximizing economic profit is tantamount to maximizing performance-related compensation. In the general case, some of the value new created will go to shareholders, insofar as they can bring innovations into the firm management and organization, and some of the new value should go to internal entrepreneurs.

\subsection{Profits and CSR}

There is a growing awareness that firms have some duty toward society at large, and should behave in so-called "socially responsible" ways. Such calls for "decentralized correction of externalities and inequalities" are motivated either by government's failures, or simply because citizens may want to promote values that are hot shared by lawmakers (Bénabou and Tirole 2010: 15).

It is not easy to arrive at a clear definition of the Corporate Social Responsibility (CSR) concept, since both in practice and theory there are many competing paradigms (Garriga and Melé 2004, Berger et al. 2007, Snider et al. 2003). In a general perspective, Kok et al. (2011: 288) define CSR as "the obligation of the firm to use its resources in ways to benefit society, through committed participation as a member of society, taking into account the society at large and improving society at large independent of direct gains of the company". If CSR were only the rational answer of the firm to a demand for "ethical products" driven by consumer tastes for such products, or investor ethical behavior, than these actions can be accommodated with neoclassical profit maximization. However, many CSR definitions involve some voluntary sacrificing of profit toward pursuing a social goal, an idea that firms should carry out social actions that go beyond what law and regulation impose on them (McWilliams and Siegel 2001; Wagner-Tsukamoto 2005, 2007, Bénabou and Tirole 2010).

It goes beyond the scope of this paper to provide an analysis of existing CSR actions and outcomes. As already mentioned, firms implemented what we would define as CSR actions well before the concept reached the management and economics literature. If the social role of business is to make positive profits, and if those profits go to the internal entrepreneurs who generated them, there is nothing to prevent CSR actions at firm level, if entrepreneurs voluntarily decide to share some of their profit with society at large. In this perspective, CSR results from a misalignment of the entrepreneurs values with those of the lawmakers.

There is no universal guide on how a company can engage in such external profit-sharing actions. Sometimes the corporate charter includes such a profit-sharing rule, and entrepreneurs can selfselect: people in agreement with this rule will join the corporation, others will look for work elsewhere. The management team can devise a way of sharing economic profits with society at any point in time, but its implementation can only succeed if it builds on values shared by all the internal entrepreneurs.

\footnotetext{
${ }^{18}$ Milton Friedman was an experienced economist and would not confuse accounting profits with economics profits (see Friedman 1966).

${ }^{19}$ The risk-adjusted opportunity cost capital for shareholders is higher than for bondholders, given their higher exposure to losses.
} 


\subsection{A summary view}

Table 1 shows a summary comparison between perspectives on economic profits in the four theories of the firm considered so far. The ownership theory of the firm can be seen as an extension of the neoclassical perspective to the shareholder-owned corporation; the entrepreneurship theory is our extension of the Austrian theory of the firm. All firms are assumed to operate in a very competitive environment, where they do not abuse market power and abide by the rule of law.

\begin{tabular}{|c|c|c|c|c|}
\hline $\begin{array}{l}\text { THEORY OF THE } \\
\text { FIRM }\end{array}$ & Neoclassical & Ownership & Austrian & Entrepreneurship \\
\hline $\begin{array}{l}\text { Ownership and } \\
\text { control }\end{array}$ & Owner-manager & $\begin{array}{l}\text { Corporation - } \\
\text { shareholder owned } \\
\text { Professional } \\
\text { management }\end{array}$ & $\begin{array}{l}\text { Entrepreneur- } \\
\text { Owner-Manager }\end{array}$ & $\begin{array}{l}\text { Corporation - } \\
\text { shareholder owned } \\
\text { Professional } \\
\text { management }\end{array}$ \\
\hline Social mission & \multicolumn{4}{|c|}{ To produce goods and services demanded or to be demanded } \\
\hline Goal & Maximize profit & $\begin{array}{l}\text { Maximize } \\
\text { shareholder value }\end{array}$ & $\begin{array}{l}\text { Make positive } \\
\text { profits and increase } \\
\text { them over time }\end{array}$ & $\begin{array}{l}\text { Make positive } \\
\text { profits and increase } \\
\text { them over time }\end{array}$ \\
\hline $\begin{array}{l}\text { The normative view } \\
\text { on economic profit } \\
\text { in a competitive } \\
\text { environment }\end{array}$ & Should be zero & Should be zero & Should be positive & Should be positive \\
\hline $\begin{array}{l}\text { What if the } \\
\text { economic profit is } \\
\text { positive? }\end{array}$ & $\begin{array}{l}\text { Suspicious } \\
\text { (bar the case of } \\
\text { legal patents) }\end{array}$ & Tolerated & Good & Good \\
\hline $\begin{array}{l}\text { The origin of } \\
\text { positive economic } \\
\text { profit }\end{array}$ & Market power & Market power & $\begin{array}{l}\text { Special awareness, } \\
\text { courage in decision- } \\
\text { making under } \\
\text { uncertainty }\end{array}$ & $\begin{array}{l}\text { Special awareness, } \\
\text { creativity, } \\
\text { innovative thinking }\end{array}$ \\
\hline $\begin{array}{l}\text { Who are entitled to } \\
\text { would-be profits? }\end{array}$ & $\begin{array}{l}\text { "Antitrust } \\
\text { authorities" }\end{array}$ & Shareholders & The entrepreneur & $\begin{array}{l}\text { Internal } \\
\text { entrepreneurs, } \\
\text { whoever they are }\end{array}$ \\
\hline CSR & $\begin{array}{l}\text { Outside the scope } \\
\text { (except in very } \\
\text { specific cases) }\end{array}$ & Undesirable & Possible & Possible \\
\hline
\end{tabular}

Table 1. A comparison between four perspectives on profits

Whatever the frame of analysis, all schools of thought recognize that firms have the same important social mission: to produce desired goods and services.

As seen earlier, the neoclassical theory is axiomatic - it mainly aims at developing an explanation for the equilibrium vector of prices in the ideal world of perfect competition, and then it will address the questions of the deviations from this ideal. In the neoclassical competition, economic profit should be zero in equilibrium, otherwise it is a signal of abuse of market power.

The ownership theory of the firm claims to provide foundations for understanding the real-life corporation, considering shareholders as the ultimate owners of the firm. The stated goal of 
maximizing shareholder value builds on an implicit requirement that the firm should make durable positive economic profits.

The Austrian school of economics offers a subtler description of the ongoing adjustment of the economy, and the permanent corporate quest to outperform rivals. Competition is a process, not an outcome of the process; in this context, positive economic profits signal that firms are moving in the right direction, and fulfilling their social mission.

The Entrepreneurship theory of the firm would extend this analysis by suggesting that these profits should primarily go to the people who created them, the internal entrepreneurs.

\section{Conclusion}

This paper has analyzed the role of business in the market economy, focusing on the concept of economic profit and its ethical dimension. To do so, it systematically compared the foundations and implications of two important theories of the firm, namely the neoclassical and Austrian economics theories.

Classical writers thought us that firms play a substantial social role: to deliver demanded goods and services in the most efficient way, and to create new goods and services that will fulfill future needs. This ongoing quest for innovation and efficiency is first of all beneficial to consumers, who have access to goods at prices below what they would be prepared to pay. Companies also provide people with jobs, and investors with a fair return on their investment. These are major achievements, for which the capitalist system should be given full credit. Admittedly, in any free society there will always be freeloaders. And there are notorious cases of corporate misbehavior and law breaching, such as the outrageous earnings manipulation at Enron in 2001, cartels set up by seemingly successful firms, carelessness in managing industrial risk (incidents at BP deep sea drilling and Tepco nuclear power production are just two recent examples), etc. But compared to the thousands of firms doing business throughout the world, these are exceptions rather than the rule. Most companies do their job and do it by respecting business laws and contracts (Campbell 2007).

This being said, are profits representative of a good or a bad ethical outcome?

In the Austrian economics perspective, competition is understood as a process where everyone tries to do better than his rivals in the market. In this environment, the special people able to detect inefficiencies and find solutions to eliminate them are the entrepreneurs. Even if an entrepreneur's main motivation is to make a profit, consumers will be the final beneficiaries of his action. But there is no reason why this analysis should not integrate other motives for becoming an entrepreneur. The potential entrepreneur will cultivate a specific form of awareness and alertness, which allows him to move ahead of the rest. He can foresee where technological progress will take us in the years to come, dare to address new technological challenges and propose new solutions and new products.

In a less visible but no less important capacity, entrepreneurship has been active within corporate boundaries for many years now; modern companies try to develop complex systems of management able to support internal entrepreneurship, defined as an opportunity and ability to innovate at every stage of the production and decision process.

So in a competitive environment, a positive profit signals that the firm is successfully performing the function for which it was created, i.e. to produce demanded goods and services in the most efficient way, making the fullest use of its entrepreneurs' ability to detect and remove market inefficiencies. Trying to increase profits over time is thus fully consistent with firms fulfilling their social role.

Who should claim this profit?

Following the finder-keeper principle first stated by Kirzner (1989), this paper argues that the legitimate claimants to any economic profits are the internal entrepreneurs. In practice, many 
companies have implemented performance-related pay systems that automatically transfer a large chunk of the profits to the people who created them.

One important objective of this paper was to apply this profit analysis to the modern shareholderowned corporation. According to the dominant ownership theory of firms, managers are called to run the firm in the interest of the shareholders; their job is to maximize shareholder value, itself directly allocated to shareholders' future cash flow. But if a large share of economic profits should go to internal entrepreneurs, this traditional recommendation goes in the wrong direction. Yes, firms should make positive profits and increase them over time by unleashing entrepreneurial talent; no, they should not maximize shareholders' cash flow, they only need to provide shareholders with the fair, risk-adjusted cost of capital (which can be quite high).

To sum up, traditional neoclassical and libertarian economists teach us that companies do good when:

- They deliver goods and services with full respect of their consumers and partners - by abiding the law, and without engaging in deception, fraud or abuse of market power.

- They make positive profits and try to increase them over time;

- They compensate people who place their resources under the control of the firm at a fair price; in a competitive environment, the fair price is the market price.

In addition to these claims, our entrepreneurship theory of the firm would suggest that firms doing good implies that:

- For shareholders, the appropriate reward is the opportunity cost of equity, fully adjusted for the project's risk;

- Firms should redistribute economic profits towards the internal entrepreneurs, i.e., that group of special people able to innovate and remove inefficiencies within the company.

The ongoing calls for firms to engage in CSR actions are not inconsistent with firms making positive profits and transferring a significant share of those profits to internal entrepreneurs, who are free to decide to share their gain with less advantaged outsiders.

Like many studies in business ethics, this short paper raises several important questions, answering some and leaving many others unanswered. One implicit assumption was that innovation, creativity and dynamism are to be preferred over controls and excessive regulation leading to sluggish growth. Yet some crises may be related to excessive innovation which, with no social control, can became disruptive, and the question arises of whether too much innovation brings its own risks. Another implicit assumption throughout this text was that human beings have values, and the majority of them will behave well. This positive opinion on our fellow humans extends to entrepreneurs. If entrepreneurs are good people, not only is their action good, but we can trust them to make good use of their profits. Further research could seek to establish whether or not this is in fact the case.

Acknowledgments. The author would like to thank participants to the First International Workshop on The Role of Business in Society and the Pursuit of the Common Good, ESSEC Business School, Cergy, 7-8 Mars 2012 as well as Hamid Bouchikhi and André Fourçans for their suggestions and remarks on an early version. 


\section{References}

Anscombe, G. E. M., 1958, Modern moral philosophy, Philosophy, 33, 124, pp.1-19.

Alchian, Armen and Harold Demsetz, 1972, Production, information costs and economic organization, American Economic Review, 52, 5, pp. 777-795.

Aristotle, 1991, Nicomachean Ethics, Jonathan Barnes Ed., Bollinger Series.

Arnold, Scott N., 1987, Why profits are deserved, Ethics, 97, 2, pp. 387-402.

Athanassoulis, N., 2004. Virtue Ethics, Internet Encyclopaedia of Philosophy, http://www.iep.utm.edu/v/virtue.htm.

Audi, Robert, 2012, Virtue ethics as a resource in business, Business Ethics Quarterly, 22, 2, pp. 273291.

Beger, Ida E., Cunningham, Peggy H and Minette E. Drumwright, 2007, Mainstream corporate social responsibility: Developing markets for virtue, California Management Review, 49, 4, pp. 132-146.

Berle, Adolf A. and Gardiner C. Means, 1932, The Modern Corporation and Private Property, New York, Commerce Clearing House Inc.

Bénabou, Roland and Jean Tirole, 2010, Individual and corporate social responsibility, Economica, 77, 305, pp. 1-19.

Brown, Grant A., 1992, Are profits deserved?, Journal of Business Ethics, 11, 2, pp. 105-114.

Blair, Margaret, 1995, Ownership and Control, rethinking Corporate Governance for the Twenty-first Century, The Brookings Institution, Washington DC.

Burgelman, Robert A., 1983a, Corporate entrepreneurship strategic management: insights form a process study, Management Science, 29, 12, pp. 1349-1364.

Burgelman, Robert A., 1983b, A process model of internal corporate venturing in the diversified major firm, Administrative Science Quarterly, 28, 2, pp. 223-244.

Camenisch, Paul F., 1987, Profit: Some moral reflections, Journal of Business Ethics, 6, 3, pp. 225-231.

Coase, Ronald, 1937. The nature of the firm, Economica, 4, 16, 386-405.

Cornwall, Jeffery R. and Michael J. Naughton, 2003, Who is the good entrepreneur? An exploration within Catholic social tradition, Journal of Business Ethics, 44, 1, pp. 61-75.

Clark, John Bates, 1914, Social Justice Without Socialism, Houghton Mifflin.

Dobb, Maurice, 1929, Russian Economic Development since the Revolution, Londres, Routledge \& Kegan Paul, $437 \mathrm{p}$.

Fama F. and Michael C. Jensen, 1983, Separation of ownership and control, Journal of Law and Economics, 26, 2, pp. 301-325.

Friedman, Milton, 1966, The methodology of positive economics, In: Essays In Positive Economics, University of Chicago Press, Chicago.

Friedman, Milton, 1962, Capitalism and Freedom, University of Chicago Press, Chicago.

Garriga, Elisabet and Domènec Melé, 2004, Corporate social responsibility theories: Mapping the territory, Journal of Business Ethics, 53, 1-2, pp. 51-71.

Gompers, Paul Alan and Joshua Lerner, 2004, The Venture Capital Cycle, MIT Press.

Goodpaster, Kenneth E. and John B. Mathews, Jr., 1982, Can corporations have a conscience?, Harvard Business Review, January-February, pp. 1-9. 
Gordley, James, 2002, Virtue and the ethics of profit seeking, Rethinking the Purpose of Business: Interdisciplinary Essays from the Catholic Social Tradition, Notre Dame, University of Notre Dame Press, Indiana, US.

Hood John, 1998, Do corporations have social responsibilities?, Free enterprise creates unique problem-solving opportunities, The Freeman on Line, 48, 11, http://www.thefreemanonline.org/ featured/do-corporations-have-social-responsibilities/

Hartman, Edwin M., 2011, Virtue, profit, and the separation thesis: An Aristotelician view, Journal of Business Ethics, 99, 1, pp. 5-17.

Hayek, Friedrich A., 1945, The use of knowledge in society, 1945, American Economic Review. 35, 4, pp. 519-30. Online at: http://www.econlib.org/library/Essays/hykKnw1.html.

Hayek, Friederich A., 1949, Individualism and Economic Order, Routledge and Kegan Paul, London.

Jensen, Michael C. and William C. Meckling, 1976, Theory of the firm: Managerial behavior, agency costs and ownership structure, Journal of Financial Economics, 3, 4, pp. 305-360.

Jones, Gareth R. and John E. Butler, 1992, Managing internal corporate entrepreneurship: An agency theory perspective, Journal of Management, 18, 4, pp. 733-749

Kok, Peter, Ton van der Weile, Richard McKenna and Alan Brown, 2001, A corporate social responsibility audit within a quality management framework, Journal of Business Ethics, 31, 4, pp. 285-297.

Kierulff, Herbert and Grant Learned, 2009, Limiting laissez faire profits: The financial implications, Journal of Busines Ethics, 90, 3, pp. 425-436.

Kirzner, Israel, 1973, Competition and Entrepreneurship, University of Chicago Press.

Kirzner, Israel, 1989, Discovery, Capitalism and Distributive Justice, Basil Blackwell.

Knight, Frank, 1971, Risk, Uncertainty and Profit, Chicago University Press, Chicago. Online at: http://www.econlib.org/library/Knight/knRUP.html .

Koehn, Daryl, 1995. A role for virtue ethics in the analysis of business practice, Business Ethics Quarterly, 5, 3, 533-539.

Lawler, Edward E., 1990, Strategic pay: Aligning organizational strategies and pay systems. The Jossey-Bass management series. San Francisco, CA, US: Jossey-Bass., 308 pp.

Moore, Geoff, 2008, Re-imagining the morality of management: A modern virtue ethics approach, Business Ethics Quarterly, 18, 4, pp. 483-511.

Murphy, Patrick E. 1999. Character and virtue ethics in international marketing: An agenda for managers, researchers and educators, Journal of Business Ethics, 18, 1, pp. 107-124.

Peterson, Richard A. and Berger David G., 1971, Entrepreneurship in organizations. Evidence from the popular music industry, Administrative Science Quarterly, 16, 1, pp. 97-106.

Pinchot, Gifford and Pinchot, Elizabeth, 1993, The End of Bureaucracy and the Rise of the Intelligent Organization, Berrett-Koehler Publishers, San Francisco.

Primeaux, Patrick and John Stieber, 1994, Profit maximization: The ethical mandate of business, Journal of Business Ethics, 13, 4, pp. 287-294.

Schader, David E., 1987, The corporation and profits, Journal of Business Ethics, 6, 8, pp. 589-601.

Schumpeter, Joseph, 1911, Theorie der wirtschaftlichen Entwicklung, Berlin; Translated in English, 1934, Theory of Economic Development, Harvard University Press, Cambridge. 
Snider, Jamie, Ronald P. Hill, and Diane Martin, 2003, Corporate social responsibility in the $21^{\text {st }}$ century: A view from the most successful firms, Journal of Business Ethics, 48, 2, pp. 175-187.

Smith, Adam, 1759, The Theory of Moral Sentiments, Macmillan, London.

Solomon, Robert C., 2003, Victims of circumstances? A defense of virtue ethics in business, Business Ethics Quarterly, 13, 1, pp. 43-62.

Solomon, Robert C., 1992, Ethics and Excellence. Cooperation and Integrity in Business, Oxford University Press, New York.

St. Thomas Aquinas. [1485], 1920, Summa Theologica, Second and Revised Edition, Literally translated by Fathers of the English Dominican Province, Online edition: http://www.newadvent.org/summa/.

Scharder, David E., 1987, The corporation and profits, Journal of Business Ethics, 6, 8, pp. 589-601.

The Economist, 2011, The Centenarians Square-up, The Economist, June 11, 2011, pp. 55-57.

Von Mises, Ludvig, 1949, Human Action: A Treatise on Economics, Yale University Press, San Francisco. Online at: http://mises.org/Books/humanaction.pdf

Vranceanu, Radu, 2005, The ethical dimension of economic choices, Business Ethics: A European Review, 14, 2, pp. 94-107.

Vranceanu, Radu, 2007, The moral layer of contemporary economics: A virtue-ethics perspective, In: M-L. Djelic and R. Vranceanu, Moral Foundations of Management Knowledge, Edward Elgar, Cheltenham, UK, pp. 134-155.

Wagner-Tsukamoto, Sigmund, 2007, Moral Agency, Profits and the firm: Economic revisions to the Friedman theorem, Journal of Business Ethics, 70, 2, pp. 209-220.

Wagner-Tsukamoto, Sigmund, 2005, An economic approach to business ethics: Moral agency of the firm and the enabling and constraining effects of economic institutions and interactions in market economy, Journal of Business Ethics, 60, 1, pp. 75-89.

Williamson, Oliver E., 1993, Calculativeness, trust, and economic organization, Journal of Law and Economics, 36, pp. 453-486.

Williamson, Oliver E., 1985, The Economic Institutions of Capitalism, Free Press, New York.

Williamson, Oliver E., 1983, Organizational form, residual claimants and corporate control, Journal of Law and Economics, 26, 2, pp. 351-366.

Zenger Todd R. and William S. Hesterly, 1997, The disaggregation of corporations: Selective intervention, high-powered incentives, and molecular units, Organization Science, 8, 3, pp. 209-222.

Zahra, Shaker A., Daniel F. Jennings and Donald F. Kuratko, 1999, The antecedents and consequences of firm-level entrepreneurship: The state of the field. Entrepreneurship Theory and Practice, 24, 2, pp. $45-65$. 
ESSEC Business School Avenue Bernard Hirsch BP 50105

95021 Cergy-Pontoise Cedex France

Tél. +33(0)134433000

$\mathrm{Fax}+33(0) 134433001$

www.essec.fr

\section{ESSEC Executive Education} CNIT BP 230

92053 Paris-La Défense France

Tél. +33(0)146924900

Fax +33 (0)1 46924990

http://formation.essec.fr

ESSEC Business School

Singapore Campus

100 Victoria Street

National Library Building \# 13-02

Singapore 188064

essecasia@essec.fr

Tél. +6568849780

Fax +6568849781

www.essec.edu

Informations

Alison Bougi

+33 (0)134433358

bougi@essec.fr

www.essec.fr

research.center@essec.fr

ISSN 1291-9616 